\title{
The Effectiveness Inhibition Filtrate BacteriocinsLactobacillus acidophilus Toward Contaminants Bacteriafrom Swordfish (Auxis rochei) Stew
}

\author{
Rieny Sulistijowati* Jetty Nurhajati** Insawosami Awom** \\ * Faculty of Marine and Fisheries.Gorontalo State University \\ **Padjadjaran University \\ PO BOX 5, Zip Code 96128 Indonesia \\ rinysulistijowati@gmail.com
}

\begin{abstract}
This research was conducted to know the effectiveness of filtrate bacteriocin Lactobacillus acidophilusaccording to concentrations toward zone of growth inhibition contaminant bacteria from swordfish(Auxis rochei)stew. This research was an experimentally research conducted in laboratory of Food Chemical Research Center of LIPI Bandung used completely randomized design with two replications. Species of contaminant bacteria used wereBacillus sp. (RR2) (Da, Te, Amp, Sxt), Staphylococcus aureus $(R 4)$ and Staphylococcus aureus $(R 5)(D a)$ witha range of concentration the filtrate bacteriocin culture L.acidophilus50,60, 70, 80, 90 and 100\%. The parameters were diameter (mm) of the zones of bacterial growth inhibition.The Results showed that treatment with filtrate of bacteriocin concentration 50 to $100 \%$ effective can inhibition the growth of bacterial contaminants. This treatment privide that the filtrate bacteriocin of culture L.acidophilus can be used as bio-preservativein the swordfish stew.
\end{abstract}

Keywords: Bacteriocins, Lactic Acid Bacteria,Contaminant bacteria, Swordfish

\section{Introduction}

Wordfish is the object of comercial tuna to be exported as wood fish known as arabushi from Nort Sulawesi Province of Indonesia. The processing of wooden fish (arabushi) includesboiled, curied and drained, then soaked in water and plucked thorns. While immersed in water susceptible bacteria from contaminat water or the hands of workers and the equipment used (BSN,[1]).

Bacterial contaminants often cause spoilage in some foods that have been process (cooked) or raw materials. Bacterial contaminants from fish i.eSerratia, Micrococcus, Bacillus, Achromobacter, Pseudomonas, Staphylococcus, and Flavobacterium (Banwards, [2]). Some strains of the bacteria contaminants are resistant toward antibiotics. It is done by way of preservation of these contaminants destroy bacteria. It can be done by using L.acidophilus bioensiling preservation. The effectiveness of bacteriocins produced by L.acidophilus provide opportunities to reduce or bacterial contaminants safely(Ogunbanwo,[3]).Some of the studies support the implementation of this research are for examples:(Sulistijowati, et al., [4]) state that the treatment of inoculum Lactobacillus acidophilus immersion time 90 minutes gave the best result for absence of E.coli in swordfish stew (Auxis rochei). (Sulistijowati, et al., [5])state that the culture age 18 hours of immersion time in 90 minutes inhibitory Coliform group up to MPN 0 with control MPN 2.63 in comparison without soaking time or 2 log cycle inhibitory Coliform bacteria group. In addition, (Santoso, [6]) the use bacteriocins production of L.Ed plantarum 22 as apreservative in products such as fish and shrimp pasta can reduce bacterial contaminants during storage. 
The objective of this research bacterial contaminants from boiled swordfish stew that were resistant to antibiotics. The value of the Minimum Inhibitory Concentration (MIC) of the filtrate L.acidophilus bacteriocins and the extent to which the effectiveness of L.acidophilus bacteriocins by concentration of the filtrate became the choice of study.Identification of this research were: The first whether the bacteria found contaminants of swordfish stew that are resistant to antibiotics; The second how much the value of the Minimum Inhibitory Concentration (MIC) of the filtrate L.acidophilus bacteriocins toward every strain bacteria contaminants of swordfish stew; The third how of effectiveness filtrate L.acidophilus bacteriocins according to the concentration toward contaminant bacterial growth inhibitory zone .

The intent of this study was to determine the effectiveness of the culture filtrate L.acidophilus bacteriocins toward contaminants bacterial of swordfish stew that was resistant to multiple antibiotics. While the purpose of this study is to obtain an effective concentration of the filtrate bacteriocins of $\mathrm{L}$. acidophilus to inhibit bacterial contaminants from boiled swordfish that can be used as an agent biopreservative. The usefulness of this study is to provide information about the benefits of bacteriocins L.acidophilus filtrate to inhibit the growth of bacterial contaminants from boiled sword fish so that it can be used as a new biopreservative.

\section{Materials And Methods}

\subsection{Materials and Equipment}

Materials used in this study were: L.acidophilus bacterial isolates available in the laboratory of Chemistry LIPI Bandung. Test bacteria used in this study were isolated from bacterial contaminants stew meat tuna. Medium and chemicals used were alcohol 70 and $95 \%$, antibiotics, Brain Heart Infusion (BHI) Agar and Broth (Oxoid), sugar cane broth, disinfectants, crystal violet solution, Lugol, oil immersio, Man ROGOSA Sharpe (MRS) broth (Oxoid, CM 359), Mueller Hinton (MH) agar (Oxoid CM 337, Nutrient agar (NA) (Oxoid CM 3B), $0.9 \% \mathrm{NaCl}$ physiological, and standardization $\mathrm{Mc}$ Farland 1 $\left(3 \times 10^{8}\right.$ Colony Forming units $(\mathrm{CFU} / \mathrm{ml})$.Equipment used in this study were:autoclave, incubator, glass equipment, laminary air flow, antibiotic paper,micrometer size millipore membrane.

\subsection{Research Method Phase I}

\section{Isolation, Identificationand Characteristics of Bacterial Contaminants of Swordfish Stew}

The method used a survey method in the laboratory and the results will be discussed in the descriptive customized with previous results. The test resistance patterns using three strains of bacteria contaminants were Bacillus sp . (RR2) Da, Te, Amp, SXT), S. aureus (R4) and S. aureus (R5) (Da) and six antibiotics that Clindamycin (DA.2), Tetracycline (Te.30),Amikacin (AK.30), Ampicillin (AMP.10), Gentamycin (CN.10), Chloramphenicol (C.30), Cotrimoxazole (SXT.25), Amoxicillin Clavulanic Acid (AMC.30). Observations were made by looking at the amount of bacterial growth inhibition zone contaminants.

\section{Sterilization Equipment and Materials}

Sterilization and autoclaving the medium at $121^{\circ} \mathrm{C}$ and a pressure of $1 \mathrm{~atm}(15 \mathrm{lbs})$, a maximum of $1.5 \mathrm{~atm}$ for 15 minutes . 


\section{Isolation of Bacteria Contaminants swordfish stew}

The first fish weeded, discarded gills and entrails, then washed with water and then boiled for $30 \mathrm{~min}$ at $80^{\circ} \mathrm{C}$ temperature. Then the fish drained until cool, then put the fish in a container of water while using tweezers plucked prickly, then drained \pm 5 hours in a dry place at room temperature. Furthermore, the fish ready to use for the isolation of bacteria. Isolation of bacterial contaminants was conducted using serial dilutions in physiological $\mathrm{NaCl}$ solution. A total of $25 \mathrm{~g}$ of fish meat samples put in $250 \mathrm{~mL}$ of $0.9 \%$ sterile physiological saline, and then $1 \mathrm{~mL}$ of sample dilution sampled into 10-2 - 10-9 each containing $9 \mathrm{ml}$ of physiological saline. Three final dilution in each sample plating is done, and then incubated at $37^{\circ} \mathrm{C}$ for $24-48$ hours. After the incubation perio, the growth of bacterial colonies observed, and then purified on medium Nutrient Agar (NA), in a petri dish and incubated for 24 hours at $37^{\circ} \mathrm{C}$ (Cappuccino,Sherman[7]).

\section{Gram Staining}

Gram staining was conducted to determine the properties of the bacteria to a type of staining and for identification. Physiological saline dripped on object glass and then the bacteria in the test loop streaking the glass object. Mixture dried then fixed three times. Mixture is cooled and then the preparations spilled with carbolic gentian violet dyes. Allowed to stand for 30 seconds. Excess dye was washed with water and discarded . Added Lugol (iodine : potassium iodide : distilled water $=1: 2: 300$ ) as a substance, for 30 seconds. Then washed with water. Preparations were washed with $96 \%$ alcohol for 2 seconds fucshin for comparison spilled water for 30 seconds, then washed with water. The results of staining, gram-positive bacteria purple and gram-negative bacteria pink (Cappuccino,Sherman [7]).

\section{Biochemistry Test}

Test Biochemistry Sugars and Indole, Methyl Red, Voges Proskauer, and Citrate (IMViC ). Bacteria Gram stain results that have been known to be Gram- positive or Gram- negative, further observed by biochemical testing media sugars are glucose , lactose, mannit, maltose and sucrose and peptone water media IMViC ie, methyl red, Voges Proskauer and citrate(Cappuccino,Sherman [7]).

\section{SugarTest}

Colonies of bacteria to be tested were taken of the loop and then inoculated into the medium of candy in a row on all test media sugars (glucose, lactose, mannit, maltose and sucrose). Then incubated at $37^{\circ} \mathrm{C}$ for 24 hours. After an incubation period observed color changes in the medium and the formation of gas in the Durham tube (Cappuccino,Sherman [7]).

\section{IMViCTest}

Colonies of bacteria to be tested were taken of the loop and then grown in medium peptone water, methyl red ( MR ), Voges Proskauer (VP) and citrate as planting on slopes . Then the medium was incubated for 24 hours at $37^{\circ} \mathrm{C}$. After incubation the media spilled reagent is then observed color changes(Cappuccino,Sherman [7]).

\section{Rejuvenation Isolates Bacteria Contamination.}

Rejuvenation is performed on BHI medium and BHI broth agar incubated for 24 hours at $37^{\circ} \mathrm{C}$. Colonies that grow then grown into a $10 \mathrm{~mL}$ broth medium sugar broth. Bacterial isolates that grow tested in an active state. 


\section{Test Pattern toward Antibiotic Resistance Bacteria.}

Bacterial contaminants that have actively taken $1 \mathrm{~mL}$ in $9 \mathrm{~mL}$ planted to sugar cane broth, then incubated for 24 hours at $37^{\circ} \mathrm{C}$. After incubation, the bacterial suspension was made in sterile physiological saline to a turbidity equivalent to Mc Farland 1 (3x108 $\mathrm{CFU} / \mathrm{mL}$ ), in the suspensions inoculated into a sterile petri dish containing $5 \mathrm{~mL}$ of Mueller Hinton medium order and leveled throughout surface. Paper disc was placed on top of a layer of antibiotic agar using sterile forceps that had been dipped in $70 \%$ alcohol and spritus bunsen. Incubated for 24 hours at $37{ }^{\circ} \mathrm{C}$. After the inhibition zone was observed and measured using calipers.

\subsection{Research Method Phase II}

Determination of Minimum Inhibitory Concentration (MIC)

The testing effectiveness of the filtrate L.acidophilus toward bacterial contaminants from swordfish stew, conducted a preliminary test to determine the MIC values filtrate L.acidophilus bacteriocins. This research was carried out experimentally in the laboratory by using 3 strains of bacterial contaminants, namely Bacillus sp. (RR2) (Da, Te, Amp, SXT), S.aureus (R4) and S. aureus(R5) (Da), and various concentrations of filtrate L.acidophilus bacteriocinsie , $10,20,30,40,50,60,70,80,90$ and $100 \%$ were namely (C10, C20, C30, C40, C50, C60, C70, C80, C90 and C100). Observations were made descriptively by looking at the growth of bacterial contaminants on NA medium in a petri dish.

\section{Preparation of L. acidophilus Bacteriocin filtrate (Ogunbanwo et al[3])}

One mililiter of the bacterial suspension L.acidophilus who have actively grown in 9 $\mathrm{ml}$ of MRS broth and incubated for 18 hour. Then centrifuged at a speed6000 rpm at $4{ }^{\circ} \mathrm{C}$ for 15 minutes to separate the cells with the filtrate. Then filtered through millipore membrane size of 0.45 micrometer. Then the filtrate is neutralized to $\mathrm{pH} 6$ with $1 \mathrm{~N}$ $\mathrm{NaOH}$ was filtered with a Millipore 0.45 to obtain the cell-free supernatant was neutral used as bacteriocins. After the filtrate bacteriocins obtained, then performed concentration of 10, 20, 30, 40, 50, 60, 70, 80, 90 and $100 \%$ under exposed in UV light for 40 minutes. Furthermore MIC testing.

\section{Rejuvenation Isolates Bacteria Contamination}

Rejuvenation was done on medium BHI broth and BHI agar incubated for 24 hours at $37^{\circ} \mathrm{C}$.

\section{Determination of Minimum Inhibitory Concentration (MIC)}

MIC conducted to determine the minimum concentration and to determine the concentration of the filtrate bacteriocins L.acidophilus best in inhibiting the growth of bacterial contaminants from swordfish stew. The determined MIC done same procedures, bacterial contaminants which have taken 1 ose active streak in BHI and in order then incubated at $37^{\circ} \mathrm{C}$ for 24 hours. After an incubation period scraped off and put in a $0.9 \%$ sterile physiological saline and centrifuged $4000 \mathrm{rpm}$ at $4^{\circ} \mathrm{C}$ for $10 \mathrm{~min}$ for the deposition of bacterial cell. Results centrifugation was washed with $0.9 \%$ sterile physiological saline 2 times and centrifuged, which the results are comparable to the turbidity of Mc Farland $1\left[3 \times 10^{8} \mathrm{CFU} / \mathrm{mL}\right]$. Subsequently $1 \mathrm{~mL}$ of the bacterial suspension was added to a contaminant in $1 \mathrm{~mL}$ of filtrate bacteriocins at each concentration was then taken of the loop and in strik on NA medium that had been frozen in a sterile petri dish. Incubation for 24 hours at $37^{\circ} \mathrm{C}$. Observations were made by looking at the growth of bacterial contaminants on NA medium in a petri dish . 


\subsection{Research Method Phase III}

\section{Testing Effectiveness Filtrate Bacteriocins L.acidophilustoward Contaminants Bacteria from Swordfish stew.}

The effectiveness of the filtrate bacteriocins L.acidophilus test against bacterial contaminants of swordfish stew. The study was carried out experimentally in the laboratory by using a completely randomized design factorial $3 \times 7$ with 2 repetitions. The first factor is the 3 strains of bacterial contaminants, namely Bacillus sp (RR2) (Da, Te, Amp, SXT); S.aureus (R4) and S. aureus (R5) (Da). Factor II filtrate bacteriocin concentration were used, namely co ( $0.9 \%$ physiological saline as a control), c1 , c2 , c3, c4, c5 , and c6 (50, 6, 70, 80,90 and $100 \%$ ) with incubation to 18 hours. Each treatment was repeated 2 times, experimental total 42 units. Parameters were observed to test the effectiveness of bacteriocins was formed inhibition zone diameter $(\mathrm{mm})$. The data were analyzed statistically by ANOVA analysis followed by Duncan 's Multiple Range Test (DMRT) if significantly different .

Equipment and MaterialsSterilization and autoclaving the medium at $121^{\circ} \mathrm{C}$ and a pressure of $1 \mathrm{~atm}(15 \mathrm{lbs})$, a maximum of $1.5 \mathrm{~atm}$ for 15 minutes.

\section{Rejuvenation Isolates Bacteria Contamination}

Rejuvenation is done on medium BHI broth and BHI agar incubated for 24 hours at 37 ${ }^{\circ} \mathrm{C}$.

Determination of the effectiveness testfiltrate bacteriocins has been done according to method illustrated by Bundesgesundhetsrat,1976 in (Nurhajati [8]). The effectiveness test of the filtrate Bacteriocins L.acidophilus performed by the agar diffusion method (paper disc). Suspension of test contaminants bacteria that has been activated, $1 \mathrm{~mL}$ were taken and put in $9 \mathrm{~mL}$ of sugar cane brot, incubation at $37^{\circ} \mathrm{C}$ for 24 hours. Then $0.1 \mathrm{~mL}$ of the bacterial suspension was poured on a petri dish and then $20 \mathrm{~mL}$ of sterile $\mathrm{MH}$ medium that is poured into sterile petri already containing suspensions were homogenized. After freezing medium, paper disc containing $0.05 \mathrm{~mL}$ of the filtrate bacteriocins sterile was placed above medium. Incubated at $37^{\circ} \mathrm{C}$ for 24 hours . Observations were made by measuring the inhibition zone diameter of inhibition zone based around the paper discs were formed after the incubation period.

\section{Results and Discussion}

\subsection{The Isolation and Identification of Bacteria Contaminants from swordfish Stew}

Based on the results of isolation of bacterial contaminants from swordfish stew obtained 10 isolates of bacterial contaminants and after Gram staining of bacterial contaminants known that the tenth were Gram-positive bacteria. From the results of gram staining selected 4 isolates of bacteria have different cell shape and will further tested antibiotic resistance patterns. These four isolates namely R3(rods,sporulating); R4 (cocci not sporulating); R5 (cocci, not sporulating ) and RR2(trunk spora) .

Gram staining results showed that the ten isolates of bacterial contaminants isolated from tuna fish stew are Gram- positive. These can be caused by Gram- positive bacteria generally form spores which are relatively resistant to heat. In addition to the Grampositive bacteria are more resistant to physical interference or mechanical disturbances (such as very high given the pressure ) compared with Gram-negative bacteria it is caused Gram-positive bacterial cell wall consists of a very thick peptidoglycan which gives rigidity to maintain cell integrity (Banwart[2]). So the selection of 4 bacterial isolates determined by the form of the bacteria. Three of the ten isolates of bacteria are rod-shaped 
and 7 isolates are cocci-shaped, the bacterial isolates are selected rod-shaped bacteria and cocci-shaped bacteria. Four bacterial isolates have been subsequently identifie. The results show that the identification of the four bacterial isolates found two types of bacteria, namely Bacillus sp and Staphylococcus aureus.Based on the test resistance patterns can be seen that the type of Bacillus sp. (RR2) and Bacillus sp. (R3) have similarities in patterns of resistance to antibiotics whereas S. aureus (R3) have the same pattern of resistance to S. aureus(R5) and for S. aureus (R4) have different patterns of resistance to S. aureus (R3) and (R5). It can be seen that there are three different bacterial strains based on resistance patterns to antibiotics that Bacillus sp.(RR2) (Da, Te, Amp, SXT), S. aureus (R4) and S. aureus (R5)(Da).

According (Ogunbanwo et al[3]) stated that some fish pathogenic bacteria resistant to multiple antibiotics. Bacterial resistance to an antibiotic can be caused by drugs (antibiotics) can not reach the place of work in the microbial cell, microbial inactivation and drug itself or due to the transfer of resistant genes have been through conjugation, transformation or transduction of other bacteria. The sensitivity of the bacteria to an antibiotic can be caused due to the mechanism of action of antimicrobial that interfere with the metabolism of cells, inhibiting cell wall synthesis, interfere with cell membrane permeability, inhibits the synthesis of proteins and nucleic acids of microbial cell damage.

\subsection{The Minimum Inhibitory Concentration (MIC) Test}

Testing was conducted to determine the minimum concentration of the filtrate bacteriocins L.acidophilus that still have antibacterial activity against bacterial contaminants derived from tuna fish meat stew.The based on MIC test against three strains of bacterial contaminants derived from tuna meat stew can be seen that filtrate bacteriocins L.acidophilus have influence in inhibiting the growth of bacterial contaminants and have MIC values different. MIC values filtrate bacteriocins L.acidophilus can be seen in Table 1 .

Table1.Minimum Inhibitory Concentration(MIC) Values Filtrate Bacteriocins L.acidophilus

\begin{tabular}{|c|c|c|c|c|c|c|c|}
\hline \multirow[t]{2}{*}{ Bakteri } & \multirow[t]{2}{*}{ Replication } & \multicolumn{6}{|c|}{ Concentration bacteriocins $(\%)$} \\
\hline & & 50 & 60 & 70 & 80 & 90 & 100 \\
\hline $\begin{array}{l}\text { Bacillus sp. (RR2) (Da, } \\
\text { Te, Amp, Sxt) }\end{array}$ & $\begin{array}{l}1 X \\
2 X\end{array}$ & $\begin{array}{l}+ \\
+\end{array}$ & + & $\begin{array}{l}+ \\
+\end{array}$ & $\begin{array}{l}+ \\
+\end{array}$ & + & $\begin{array}{ll}- \\
+\end{array}$ \\
\hline S.aureus (R4) & $\begin{array}{l}1 X \\
2 X\end{array}$ & $\begin{array}{l}+ \\
+\end{array}$ & $\begin{array}{l}+ \\
+\end{array}$ & $\begin{array}{l}+ \\
+\end{array}$ & $\begin{array}{l}+ \\
+\end{array}$ & $\begin{array}{l}+ \\
+\end{array}$ & $\begin{array}{l}+ \\
+\end{array}$ \\
\hline S.aureus (R5) (Da) & $\begin{array}{l}1 X \\
2 X\end{array}$ & - & + & $\begin{array}{l}+ \\
-\end{array}$ & + & - & - \\
\hline
\end{tabular}

The based on Table 1 it shows that the value of MIC bacteriocins for Bacillus $\mathrm{sp}$. (RR2) (Da, Te, Amp, SXT), S. aureus (R4) and S. aureus (R5) (Da) is $50 \%$. Based on these results the determination of MIC values that will be used to test the effectiveness of filtrate bacteriocins L.acidophilus against three strains of bacterial contaminants are at concentrations of 50\%-100\%.Test results of filtrate Bacteriocin effectiveness against bacteria contaminants from swordfish stew. Observations were made by measuring the inhibition zone diameter of bacteriocin filtrate against bacteria contaminants from swordfish ( Auxis rochei ) stew can be seen in Appendics. 


\subsection{Effectiveness Filtrate Bacteriocins toward Contaminants Bacteria From Swordfish Stew}

Effectiveness filtrate bacteriocins L.acidophilus toward contaminants bacteria Bacillus sp. (RR2) (Da, Te, Amp, SXT), S. aureus (R4) and S. aureus (R5) (Da) from swordfish stew can be seen in Figure 2. The Figure 2. be seen that the effectiveness of the filtrate bacteriocins L.acidophilus concentrations of $50 \%-100 \%$ growth inhibitory regions capable of forming bacteria Bacillus sp contaminants (RR2) (Da, Te, Amp, SXT), S. aureus (R4) and S. aureus (R5) (Da) from swordfish stew. Diameter size at each different concentration. The concentration of the filtrate bacteriocins capable of forming dimeter greater inhibitory regions in the three bacterial contaminant that is $90 \%$ and $100 \%$. In this figure can also be seen that the higher the concentration of the filtrate bacteriocins diameter greater inhibitory regions. It is influenced by the concentrations of bacteriocins that can affect the content of the filtrate.

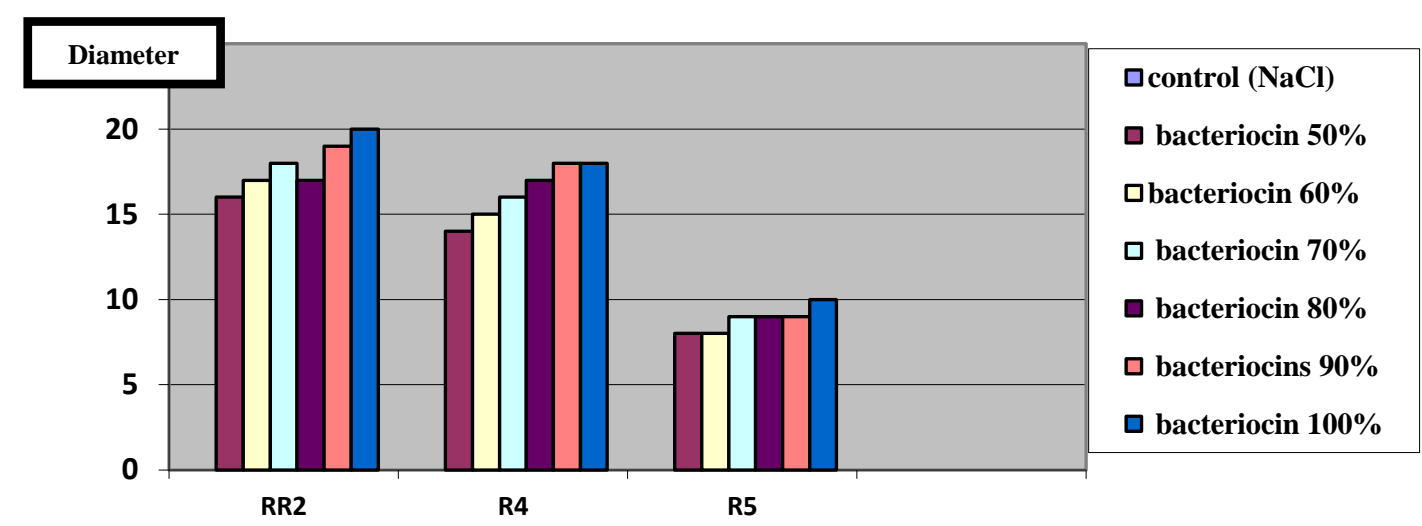

RR2 $=$ Bacillus sp. $(\mathrm{Da}, \mathrm{Te}, \mathrm{Amp}, \mathrm{Sxt})$

R4 $=$ S.aureus

$\mathrm{R} 5=$ S.aureus $(\mathrm{Da})$

\section{Figure2.EffectivenessFiltrate Bacteriocins L.acidophilus Culture Toward Contamination Bacteria From Swordfish Stew (Auxis rochei)}

The based on analysis of variance results indicatethat the type of bacterial contaminants and the provision of various concentrations of filtrate bacteriocins L.acidophilusvery real effecton bacterial growth inhibition are a diameter. This means that the formation of bacterial growth inhibition are adiameter various concentrations of culture filtrate L.acidophilus bacteriocins differ for each treatment.

Duncan's multiple rangetest used to determine differences in the effect of the inhibition zone. The results of Duncan's multiple range testof the influence of the type of bacteria to large inhibitory areas are listed in appendics. Based on diameter inhibition zone it is known that the diameter of the bacterial growth inhibitory regions bacteriocins culture filtrate L. acidophilus influenced by the type of bacterial contaminants derived from tuna meat stew.

Largevalue averagediameter ofthe growthinhibitionareabetweenS. aureusbacteria(R4) andBacillussp. (RR2) (Da, Te, Amp, SXT) showedhighly significantdifferencesarelarger thanS. aureus(R5) (Da).It can also be seen that the type of bacteria Bacillus sp. (RR2) (Da, Te, Amp, SXT) andS. aureus (R4) showed no difference in effect the formation of bacterial growth inhibition area diameter. This suggests that the growth of bacterial contaminants Bacillus sp. (RR2) (Da, Te, Amp, SXT) and S. aureus (R4) can be inhibited by bacteriocins culture filtrate L.acidophilus with the formation of growth inhibitory 
regions. As stated by (Aly, [9])that the bacteriocins produced by L.acidophilus have bacteriostatic and bactericidal effect.

It is also supported by research and (Ibrahim, Desouky [10]) who stated that antimicrobial metabolites produced by L.acidophilus effective against quality tilapia as effective at inhibiting the growth of S. aureus and other bacteria. Based on eppendix it is known that the type of bacteria S. aureus (R5) (Da) showed highly significant differences in the average value of bacterial growth inhibition area diameter smaller than the bacterial species Bacillus sp. (RR2) (Da, Te, Amp, SXT) and S. aureus (R4). This occurs because the activity of antimicrobial compounds L.acidophilus others can be bakteriostatik or bactericidal, this depends on the type and characteristics of microorganisms (Karaoglu, et al.,[11] ) and (Toddorov, Dick [12]). Besides the species of microorganisms showed different susceptibility to an antimicrobial work.

Duncan's multiple range test results on the effect of concentration of filtrate bacteriocins L.acidophilus bacteriocins against large inhibitory areas were listed in appendics. Duncan 's multiple range test results that the formation of the diameter of the area affected by bacterial growth inhibitory concentrations of filtrate bacteriocins L.acidophilus. Additionally bacteriocins culture filtrate concentration L.acidophilus $50 \%$ - $100 \%$ indicates no difference in the effect of growth inhibition area diameter forming bacteria, which means that various concentrations of filtrate bacteriocins capable of providing an inhibitory effect on the growth of strains of bacteria contaminant. According (Martiani, et al., [13]) stated that the antimicrobial compounds activity of thebacteriostatic or bactericidalagainst other microorganisms it depends on the types, characteristics and concentration of antimicrobial compounds produced.

Mechanism of action of bacteriocins in inhibiting the bacteria that attach to the cytoplasmic membrane, causing the membrane to become unstable, resulting in decreased cell viability and led to the release of the material contained within the cell nucleus so that the cells become dead (Ko, Ahn [14]) .

\section{4 . Conclusion}

In this study Effectiveness Inhibition Filtrate Bacteriocins Lactobacillus acidophilus

Toward Contaminants Bacteria from Swordfish (Auxis rochei) Stew reveals that

- There Bacterial contaminants of swordfish stewthat has been resistant to someantibioticsthat Clindamicin (DA.2), Tetracycline (Te.30), Ampicillin (AMP.10) and Cotrimoxazole (SXT 25) .

- MIC value for each contaminant different strains of bacteria Bacillus sp (RR2) (Da, Te,Amp,SXT), S.aureus (R4) and S. aureus (R5) (Da) is $50 \%$.

- Concentration of filtratebacteriocins L.acidophilus from $50 \%-100 \%$ effective in inhibiting the growth of bacterial contaminants from swordfish stew.

\section{Acknowledgment}

The author would like to thank to the Head of LIPI Chemistry Center of Bandung, Indonesia which has provided laboratory facilities during the research.

\section{References}

[1] BSN,"Ikan Kayu Bagian 3:Penanganan dan Pengolahan",SNI2691.3, (2009).

[2] G.J. Banwart, "Basic Food Microbiology", An AVI Book,(1989), p. 773.

[3] S.T.Ogunbanwo, A. I. Sanni and A. A. Onilude,"Characterization of bacteriocin produced by Lactobacillus plantarumF1 and Lactobacillus brevisOGI", African Journal of Biotechnology, vol.2, no. 8, (2003), pp. 219-227.

[4] R. Sulistijowati, J. Nurhajati and I. Amalia, " The Influence of Giving Various Concentration and Methode of Inoculum Lactobacillus acidophilus According to Immersion time For Total Escherichia 
coli in Swordfish Stew (Auxis rochei")", Proceeding International Seminar Biotechnology For Enhancement the Technical Biodiversity,UNPAD Bandung, (2010).

[5] R. Sulistijowati, "The Influence of Culture Age and Soaking TIme Range with Filtrate Lactobacillus acidophilus toward the Numberof Coliform Bacteria in Swordfish (Auxis rochei) Stew",Journal of Biology, Agriculture and Care, vol.3, no.4, (2013).

[6] E. Santoso, "Pemanfaatan Bakteriosin Produksi Lactobacillus plantarum Ed 22 Sebagai Pengawet Produk Perikanan", Makalah Bidang Teknik Sumberdaya Alam Pertanian, (2009).

[7] J.G. Cappuccino and N. Sherman,"MicrobiologyALaboratory Manual", The Benjamin/Cummings Publishing Company, Inc. Menlo Park, California,(2005), p. 528.

[8] J.S.Nurhajati, "Identifikasi Isolat Salmonella Dari Itik dan Lingkungan Sekitar Serta Pengujian Sifatsifat Biologi", [Disertasi] Universitas Padjadjaran, Bandung, (1991).

[9] E.Aly, "Chromosomal genes-mediated inhibition of intestine and foodborne pathogens by Lactobacillus acidophilus AA11", Rev Latinoam Microbio,vol.48, no. 1, (2006), pp. 24-30.

[10] S.M. Ibrahimand S.G. Desouky, "Effect of Antimicrobial Metabolites Produced by Lactic Acid Bacteria on Quality Aspect of Frozen Tilapia (Oreochromis niloticus) Filets", World Journal of Fish and Marine Scienes, vol. 1, no. 1, (2009), pp. 40-45.

[11] S.A. Karaoglu, F. Aydin, S.S. Kilic and A.O. Kilic,"Antimicrobial Activity and Characteristics of Bacteriocins Produced by Vaginal Lactobacilli", Journal Medical Science Turk, vol. 33, (2002), pp. 713.

[12] S.D. Toddorov and L.M.T. Dick, "Bacteriocin Production By Lactobacillus pentosus ST712BZ Isolated From Boza", Journal of Microbiology Bazilian, vol. 38, (2007), pp. 166-172.

[13] L.M. Martirani, N. G. Varcamontiand M. De Felice, "Purification and partial characterization of Bacillon 490, a novel bacteriocin produced by thermophillic strain of Bacillus licheniformis",Microb Cell Fact.,vol. 1, no. 1, (2002), p. 1.

[14] S.H.Ko and C. Ahn, "Bacteriocin production by Lactococcus lactis KCA2386 isolated from White Kimchi", Food Sci. Biotehnol., vol. 9, no. 4, (2000), pp. 263-269.

\section{APPENDICS}

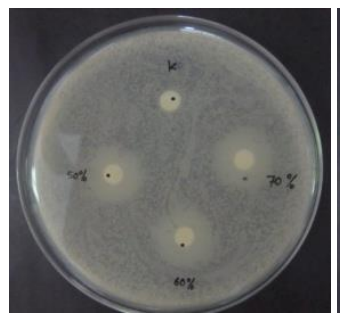

$50 \%-70 \%$

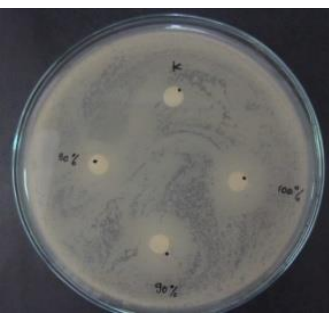

$80-100 \%$

Replication

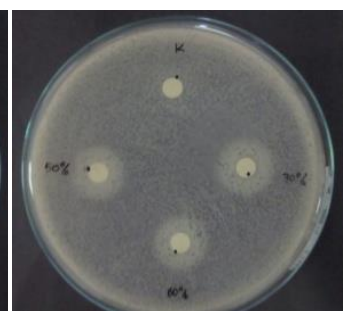

$50 \%-70 \%$

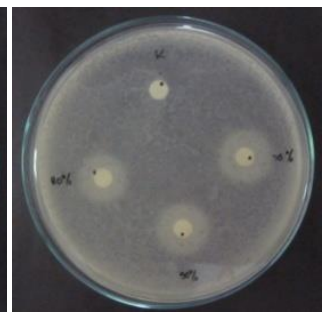

$80-100 \%$

(a) Filtrate bakteriocins toward Bacillus sp. (RR2) (Da, Te, Amp, Sxt)

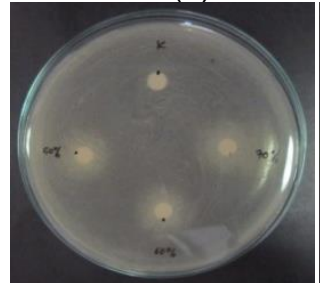

$50 \%-70 \%$

Replication I

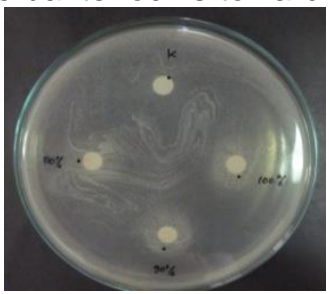

$80-100 \%$

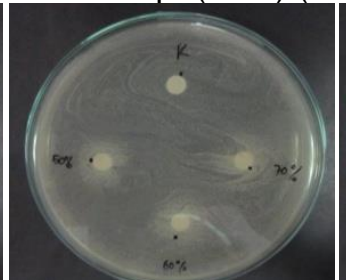

$50 \%-70 \%$

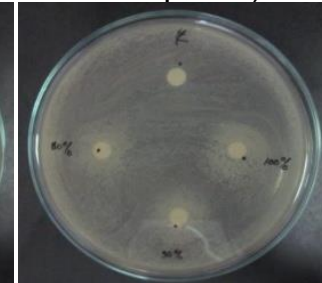

$80-100 \%$

(b) Filtrate bacteriocinstoward Staphylococcus aureus(R4)

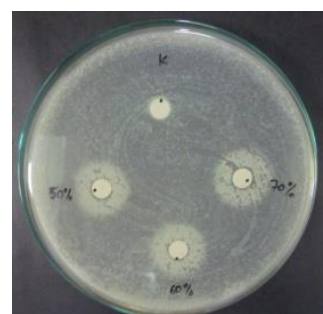

$50 \%-70 \%$

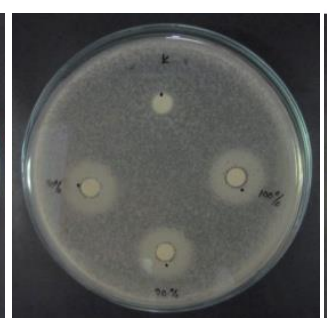

$80-100 \%$

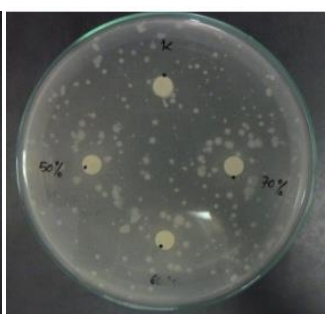

$50 \%-70 \%$

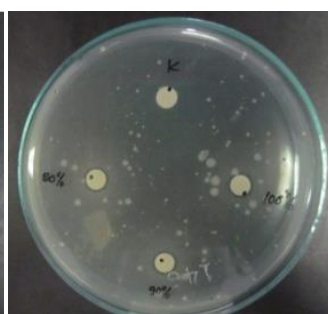

$80-100 \%$ 


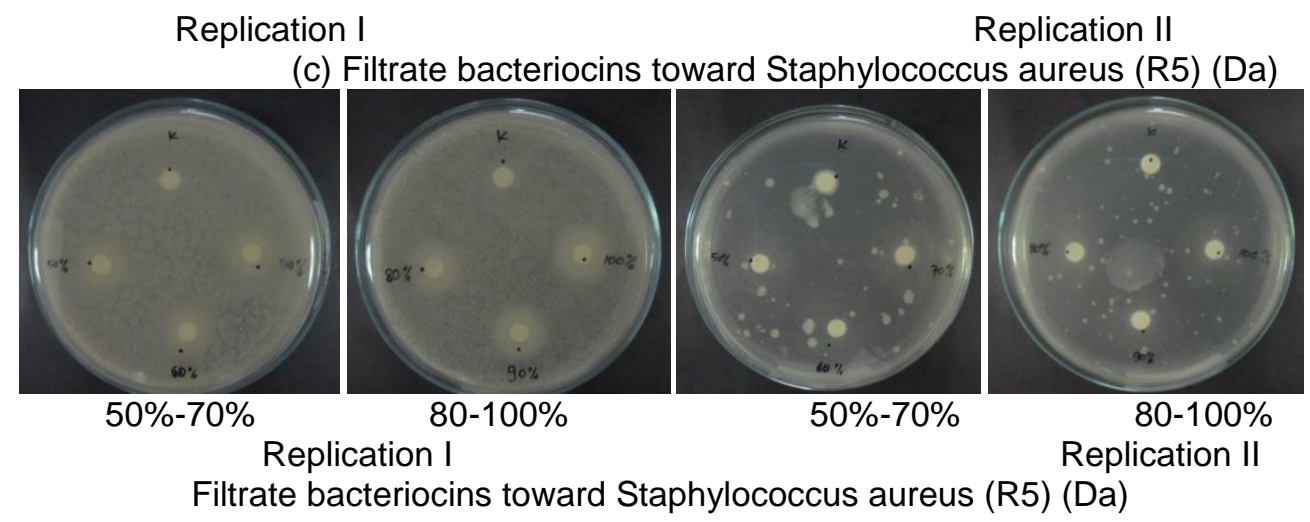

Figure 1. Diameter Inhibition

Table 1. Analysis of Varians Diameters inhibition Bacteriocins Filtrate of Lactobacilus acidophilus Culture toward Bacteria Contaminants Originating from Swordfish Stew

\begin{tabular}{|c|c|c|c|c|c|c|}
\hline \multirow[t]{2}{*}{ Sour of Varians } & \multirow[t]{2}{*}{ df } & \multirow{2}{*}{$\begin{array}{l}\text { Sum } \\
\text { squares }\end{array}$} & \multirow[t]{2}{*}{ Cs } & \multirow[t]{2}{*}{$\mathbf{F}_{\text {value }}$} & \multicolumn{2}{|l|}{$\mathbf{F}_{\text {table }}$} \\
\hline & & & & & $\mathbf{F}_{0,05}$ & $F_{0,01}$ \\
\hline Bacteria & 2 & 524.190 & 262.095 & $5.93^{* *}$ & 3.467 & 5.780 \\
\hline Concentration & 6 & 1095.143 & 182.524 & $4.13^{* *}$ & 2.573 & 3.812 \\
\hline $\begin{array}{l}\text { Interaction Bacteria } \\
\text { and concentration }\end{array}$ & 12 & 94.143 & 7.845 & 0.178 & 2.250 & 3.173 \\
\hline Galat & 21 & 927.500 & 44.167 & & & \\
\hline Total & 42 & 9005.000 & & & & \\
\hline
\end{tabular}

$\mathrm{df}=$ degreesof freedom, SS: sum of squares, Cscentralsquare,

$* *=$ Highlysignificant (differ very real) at the level oferrorof $1 \%$ according totestAnalysis of Variance

Table 2.Effect Types of Bacterial Contaminants from Swordfish Stew toward Diameter Growth Inhibition Bacteria In The Filtrate Bacteriocin

\begin{tabular}{|c|c|}
\hline Bakteria & Diaemeter Inhibition Zone (mm) \\
\hline $\begin{array}{l}\text { Bacillus sp. (RR2) (Da, Te, } \\
\text { Amp, Sxt) }\end{array}$ & $\begin{array}{c}15.36 \\
\mathrm{~b}\end{array}$ \\
\hline S.aureus (R4) & $\begin{array}{c}14.21 \\
\mathrm{~b}\end{array}$ \\
\hline S.aureus (R5) (Da) & $\begin{array}{c}7.36 \\
\mathrm{a}\end{array}$ \\
\hline $\begin{array}{l}\text { lettersaresimilarto thevertic } \\
\text { tat } 99 \% \text { degreeof confidence. }\end{array}$ & directionindicatesnot \\
\hline
\end{tabular}

Table 3. The Effect of Filtrate Bacteriocin Concentration Toward Diameter Growth Inhibition Contaminan Bacteria

\begin{tabular}{ll}
\hline Concentrasi (\%) & Diaemeter \\
& Inhibition Zone (mm) \\
\hline
\end{tabular}




\begin{tabular}{cc}
\hline Control (NaCl Phisiologis steril) & $0 \mathrm{a}$ \\
\hline 50 & $13.00 \mathrm{~b}$ \\
60 & $13.50 \mathrm{~b}$ \\
70 & $14.17 \mathrm{~b}$ \\
80 & $14.3 \mathrm{~b}$ \\
90 & $15.33 \mathrm{~b}$ \\
100 & $15.83 \mathrm{~b}$
\end{tabular}

The lettersaresimilarto thevertical directionindicatesnot significantly differentat $99 \%$ degreeof confidence.

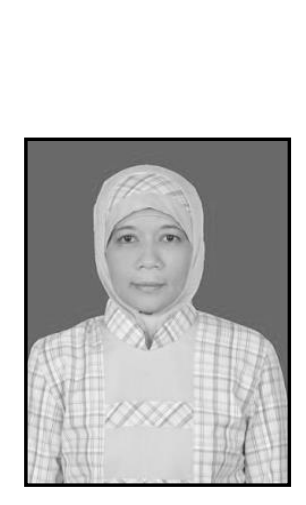

\section{Authors}

Rieny Sulistijowati S, she received her S.Pi (Fish Processing) from Samratulangi University, M.Si (Microbiology Process) from Padjadjaran Univerity, and Dr. (Fish Industri Technology) from Padjadjaran University. Worked as lecture to the Departemen Fishey Technologi, Faculty of Marine and Fisheries Gorontalo State University. Her major research interest is seafood safety, fisheries biotechnology and fisheries fermentation. She has published several Paper in International Journal and Conferences and 4 Books for fish processing. 
International Journal of Bio-Science and Bio-Technology

Vol.7, No.3 (2015) 